\title{
Hybrid Processes Evaluation of Pb(II) Removal from Wastewater Effluents
}

\author{
Bashkim Thaçi ${ }^{1}$, Salih Gashi $^{2 *}$, Nexhat Daci², Majlinda Daci-Ajvazi ${ }^{1}$ \\ ${ }^{1}$ University of Prishtina, Department of Chemistry, 10000 Prishtinë, Republic of Kosova \\ ${ }^{2}$ Academy of Sciences and Arts of Kosova, 10000 Prishtinë, Republic of Kosova
}

Received: 11 September 2020

Accepted: 13 November 2020

\begin{abstract}
The hybrid processes potential on $\mathrm{Pb}(\mathrm{II})$ removal from wastewater effluents have been investigated. Batch test conditions were carried out to examine the effects of initial metal concentration, adsorbent dose, contact time, temperature and initial solution $\mathrm{pH}$ on adsorption of $\mathrm{Pb}$ (II) ions from aqueous solution onto wheat bran. The highest adsorption efficiency was observed at solution $\mathrm{pH} 5$, contact time $30 \mathrm{~min}$ and temperature $25^{\circ} \mathrm{C}$. The adsorption equilibrium data correlate well with both Langmuir and Freundlich isotherms. Thermodynamic studies suggested the spontaneous and exothermic nature of adsorption process. The retentate of power plants wastewater sample pretreated with wheat bran was used as feed for reverse osmosis low-pressure heterogeneous membrane treatment. The high removal efficiency of $\mathrm{Pb}(\mathrm{II})$ and co-existed ions from the above wastewater sample was achieved by hybrid processes with high preference for re-use.
\end{abstract}

Keywords: adsorption, wheat bran, $\mathrm{Pb}(\mathrm{II})$, wastewater, hybrid processes

\section{Introduction}

Wastewater effluents of metal-plating and metal finishing operations, mining and ore processing operations: metal processing, battery and accumulator manufacturing operations, thermal power generation (coal-fired plants in particular) nuclear power generation etc. discharged into water and soil directly or indirectly without treatment, have become the major pollutants in water resources among others heavy metal ions. Metals such as lead, cadmium, nickel, mercury and chromium even in small concentration are the most dangerous industrial pollutants of water due to their high toxicity and non-degradability. Lead is one of the

*e-mail: salihgashi@ashak.org most toxic heavy metal found in industrial wastewater. Lead damages circulatory and central nervous system diseases of the kidneys, liver and reproductive system, basic cellular processes and brain functions. Numerous techniques have been developed for the treatment of heavy metal-bearing effluents. The conventional methods available for removal of heavy metal such chemical precipitation, ion exchange, electrochemical treatment, chemical oxidation/reduction, solvent extraction, membrane filtration etc. are costly, produce some toxic sludge and also require large energy input, which is in efficient, and non is able to completely remove $\mathrm{Pb}(\mathrm{II})$ ions.

Adsorption is recognized as an effective method for heavy metal wastewater treatment and search has been focused on the use of agricultural by-products as adsorbents for treatment wastewater effluents due to 
their selectivity, low cost and ease used. The inherent advantages and applications of biosorption have been extensively reviewed by several researchers [1-3].

Several biosorption materials have been used for lead adsorption from aqueous solutions. Groundnut hull [4], Moringa oleifera tree leave schemically modified [5], (chalf, rice husk, sesame husk, sun flowers husk), [6], peels of banana [7], etc. have been investigated to remove $\mathrm{Pb}(\mathrm{II})$ from wastewater. Moreover, Brassica nigra without any chemical pretreatment is shown to be alternative biosorbent for $\mathrm{Pb}(\mathrm{II})$ removal from aqueous solutions in form of metal complex [8]. The Peanut shell is regarded as effective economical biosorbent for the removal of toxic heavy metal ions from solution containing sodium chloride and amino acid, such as marine protein hydrolysate solution [9]. The adsorption of $\mathrm{Pb}^{2+}$ in aqueous solution onto activated carbon produced from wine making waste showed successful removal of $\mathrm{Pb}(\mathrm{II})$ from polluted water [10].

The Trapa bispinoza's peel (pretreated and modified with $\mathrm{HNO}_{3}, \mathrm{HClO}_{4}$, and $\mathrm{H}_{2} \mathrm{O}_{2}$ ) was exploited to enhance the $\mathrm{Pb}(\mathrm{II})$ removal [11].

Soya bean was used for adsorptive removal of lead and arsenic from wastewater. The adsorption by it was an exothermic process [12]. A $\mathrm{Pb}$ (II) imprinted magnetic biosorbent ( $\mathrm{Pb}$ (II)-IMB) was developed for the removal of $\mathrm{Pb}$ (II) via lead ion imprinted technology and crosslinking reactions among chitosan (CTS), Serratia marcescens and $\mathrm{Fe}_{2} \mathrm{O}_{3}$ [13]. The $\mathrm{Pb}^{2+}$ biosorption from aqueous solution by live and dead biosorbents of the hydrocarbon-degrading strain Rhodococcus sp.HX-2 was examined. It was conducted that, dead biosorbent seem to be a more effective for application in wastewater treatment [14]. The polyphenols extracted from Leucaena leucocephala residues was used for simultaneous removal of $\mathrm{Pb}(\mathrm{II})$ and $\mathrm{Cd}(\mathrm{II})$ ions from water system. They found that chemisorption might be the mechanism of the solute ion-llep-s interaction [15]. The lemon, artichoke and bean shells were used to remove $(\mathrm{Pb})$ ions from aqueous solution Bean shell was the most effective [16].

The dominance of $\mathrm{Pb}(\mathrm{II})$ during competitive biosorption from multi-metal system was reviewed. For most biosorbents $\mathrm{Pb}(\mathrm{II})$ is effectively removed from solution even in presence of other heavy metals. However, the removal of $\mathrm{Cu}(\mathrm{II}), \mathrm{Cd}(\mathrm{II}), \mathrm{Zn}(\mathrm{II}), \mathrm{Ni}(\mathrm{II})$ and $\mathrm{Cr}$ (III) would be significantly suppressed in the presence of $\mathrm{Pb}(\mathrm{II})$ [17]. The $95.7 \%$ of coomassie brilliant blue (CBB) was shown to be removed from aqueous solution onto wheat bran [18].

The membrane technology has proven to be a more favorable option in wastewater treatment processes in recent time. Pressure driven membrane processes are by so far the most widely applied membrane processes in water treatment from pretreatment to post-treatment of wastewater. Among the pressure driven membrane processes $\mathrm{RO}$ is highly known for its efficiency in separating small particles including bacteria and monovalent ions like sodium and chloride ions up to $99.5 \%$ [19]. It is evident that no adsorption nor membrane technologies could be applied individually for successful treatment wastewater of reuse standards. Therefore, the integral part in the success of membrane process is pretreatment, which do not only reduce membrane fouling but also contribute to energy utilization. The possibility of combining two or more membrane processes with each other or other forms of technologies in a hybrid fashions is also continuously being explored, developed and applied in many wastewater treatment facilities. Physicochemical methods such as coagulation/adsorption and softening have been applied in several instances to pretreated wastewater before membrane separation [20]. The purification of olive mill wastewater was studied by combination of Ultrafiltration/Reverse osmosis [21]. Hybrid membrane bio-system for sustainable treatment of oil and gas produced water and fracturing flow back water was investigated [22]. The olive waste, maize cob and wheat bran were used for removal of heavy metal ions from aqueous solutions as well as from wastewater effluents of mining flotation process. It was concluded that these biosorbents could be feasible and sustainable for pretreatment of wastewaters prior to reverse osmosis [23].

This paper aims to evaluate the removal of $\mathrm{Pb}$ (II) ions from wastewater effluents by hybrid (biosorption/ Reverse osmosis) processes.

\section{Material and Methods}

The wheat bran used in this study is a by-product of local flour factory (Dardania, Pejë, Republic of Kosova). It was washed with distilled water and dried $\left(80^{\circ} \mathrm{C}\right)$ for 20 hours. The dried samples were saved (0.1 mesh), and fractions of $>0.2 \mathrm{~mm}$ were used for experiments. The characteristics of used adsorbent are described elsewhere [23]. The sorption of $\mathrm{Pb}$ (II) ions on wheat bran was studied using batch technique. The stock solution of reagent grade $\mathrm{PbCl}_{2}$ of different concentrations $\mathrm{Pb}(\mathrm{II})\left(70,35,17.5\right.$ and $\left.7 \mathrm{mg} / \mathrm{dm}^{3}\right)$ was used in all experimental runs. The $50 \mathrm{~cm}^{3}$ of $\mathrm{Pb}$ (II) solution was equilibrated with $0.25 \mathrm{~g}$ wheat bran at different equilibrated time $(5,10,20,30,60,90$, and $120 \mathrm{~min})$. Then $50 \mathrm{~cm}^{3}$ of $\mathrm{Pb}(\mathrm{II})$ solution was treated with $(0.1,0.25$, and $0.5 \mathrm{~g}$ of adsorbent), at different temperature $(298,308,318,328 \mathrm{~K})$, and $\mathrm{pH}(3,5,7,9$, 11) in a stopped Pyrex glass flask in thermostatic shaker bath. After equilibration the suspension was filtered (MN 640m $\Theta 125 \mathrm{~mm}$ ) and retentate was used as feed for reverse osmosis experiments. The thermal power plants (Kosova B) wastewater sample of initial $\mathrm{pH} 8.35$ was treated with wheat bran and filtered with the same filter above. The clear filtrate (retentate) at $\mathrm{pH} 7.55$ without any addition of chemical agents was used in Reverse Osmosis experiment.

The concentration of metals in feed, after adsorption by wheat bran and after reverse osmosis, was 
analyzed by inductive coupled plasma optical emission spectroscopy (ICP-OS 21000DV).

The retentate of wheat bran pretreatment was subjected to heterogeneous asymmetric reverse osmosis membranes (batch 317). The reverse osmosis film details and experimental reverse osmosis procedure is described elsewhere [24, 25].

The removal percentage, ( $R \%)$, and capacity of $\mathrm{Pb}$ (II) ions per gram wheat bran at equilibrium, $q_{e}$ $(\mathrm{mg} / \mathrm{g})$ were calculated using the following equations:

$$
\begin{gathered}
R \%=\frac{C_{o}-C_{e}}{C_{o}} x 100 \\
q_{e}=\frac{C_{0}-C_{e}}{W} x V
\end{gathered}
$$

...where $C_{o}$ and $C_{e}$ are the initial and equilibrium concentrations of $\mathrm{Pb}(\mathrm{II})$ ions, respectively $\left(\mathrm{mg} / \mathrm{dm}^{3}\right), V$ is the volume of $\mathrm{Pb}$ (II) solution $\left(\mathrm{dm}^{3}\right)$, and $W$ is the weight of wheat bran used (g).

\section{Results and Discussion}

The adsorption of lead (II) ions into wheat bran was investigated as a function of the contact time, initial metal ion concentration, adsorbent dosage, temperature and initial $\mathrm{pH}$.

\section{The Effect of Initial Sorbate Concentration and Contact Time}

The effect of different initial $\mathrm{Pb}(\mathrm{II})$ ions concentration on the wheat bran at different contact times are shown in Fig 1.

The rate of $\mathrm{Pb}$ (II) binding with the wheat bran is higher in the initial stage, gradually increase, and becoming almost constant. It is evident that contact time of 30 minutes was sufficient to achieve adsorption equilibrium. Therefore, an equilibrium time of 30 minutes was selected for further all studies. The adsorbent dose determines the capacity of an adsorbent for a given initial concentration of the adsorbate. The effect of wheat bran dose and initial concentration on the adsorption of $\mathrm{Pb}(\mathrm{II})$ ions is presented in Table 1 .

The data of Table 1, indicate that as the initial $\mathrm{Pb}$ (II) ion concentration decreases, the percent removal

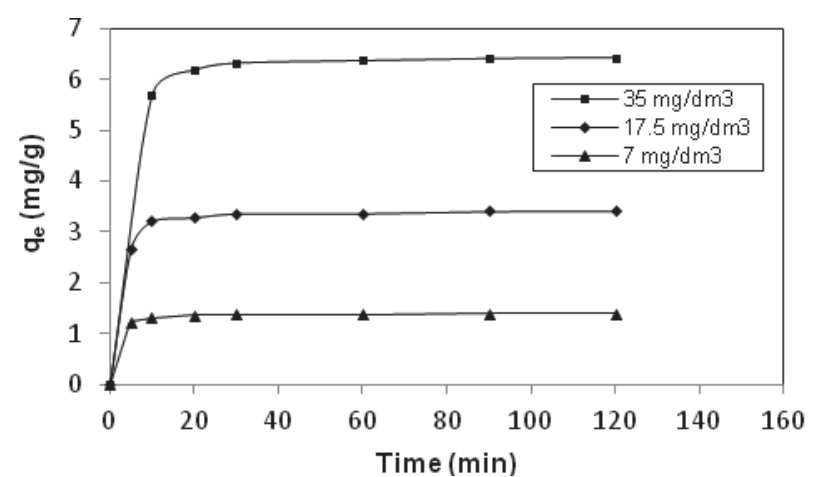

Fig. 1. The rate of adsorption of three initial $\mathrm{Pb}$ (II) ion concentrations on the wheat bran vs. contact time. Conditions: wheat bran $0.25 \mathrm{~g} / 50 \mathrm{~cm}^{3}, 25^{\circ} \mathrm{C}, \mathrm{pH}=5$.

increases. The higher removal of metal ions at lower initial concentration is due to the availability of more adsorption binding sites at the in initial stage. At lower metal ion concentrations, sufficient adsorption sites are available for the sorption of metal ions. At higher concentrations lower adsorption yield is due to the saturation of adsorption sites of adsorbent.

The adsorption percent at various doses of wheat bran from 0.1-0.5 $\mathrm{g}$ is shown in Table 1 .

Increasing the adsorbent dose increase the adsorption percent of $\mathrm{Pb}$ (II) ions, which is due to the increasing in adsorption sites of adsorbent resulting from increasing of surface area. This was expected as with increasing concentration of adsorbent more active sites become available for metal uptake. This seems to be due to the binding of almost all ions to the adsorbent and the establishment of equilibrium between the ions bound to the adsorbent and those remaining unadsorbed in solution.

\section{The Effect of Initial pH}

The $\mathrm{pH}$ is a very important parameter in adsorption process. The effect of solution of $\mathrm{pH}$ on the adsorption of $\mathrm{Pb}(\mathrm{II})$ ions on the wheat bran was investigated from pH 3-11 (Fig 2).

It could be observed that the $\mathrm{Pb}$ (II) adsorption by wheat bran increases with increasing $\mathrm{pH}$ from 3-8, for all used initial concentrations, becomes rather constant to $\mathrm{pH} 9$, and then decreases rapidly. The lowest value of lead uptake was obtained when $\mathrm{pH}$ was minimum

Table 1. Effect of adsorbent dose $\left(\mathrm{g} / 50 \mathrm{~cm}^{3}\right)$ and initial concentration on adsorption of $\mathrm{Pb}$ (II) ions on wheat bran. Conditions: 30 min, $\mathrm{pH}=5,25^{\circ} \mathrm{C}$.

\begin{tabular}{|c|c|c|c|c|c|c|c|c|c|c|c|c|}
\hline Adsorbent dose $(\mathrm{g})$ & \multicolumn{3}{|c|}{$\begin{array}{c}\text { Initial conc. of } \mathrm{Pb}^{2+} \\
\left(\mathrm{mg} / \mathrm{dm}^{3}\right)\end{array}$} & \multicolumn{4}{c|}{ Removal efficiency } & \multicolumn{4}{c|}{$\mathrm{q}_{\mathrm{e}}(\mathrm{mg} / \mathrm{g})$} \\
\hline 0.1 & & & & & 0.849 & 0.868 & 0.908 & 0.921 & 29.74 & 15.19 & 7.95 & 3.22 \\
\hline 0.25 & 70 & 35 & 17.5 & 7 & 0.893 & 0.903 & 0.962 & 0.986 & 12.49 & 6.32 & 3.37 & 1.38 \\
\hline 0.5 & & & & & 0.959 & 0.966 & 0.973 & 0.991 & 6.72 & 3.38 & 1.70 & 0.69 \\
\hline
\end{tabular}




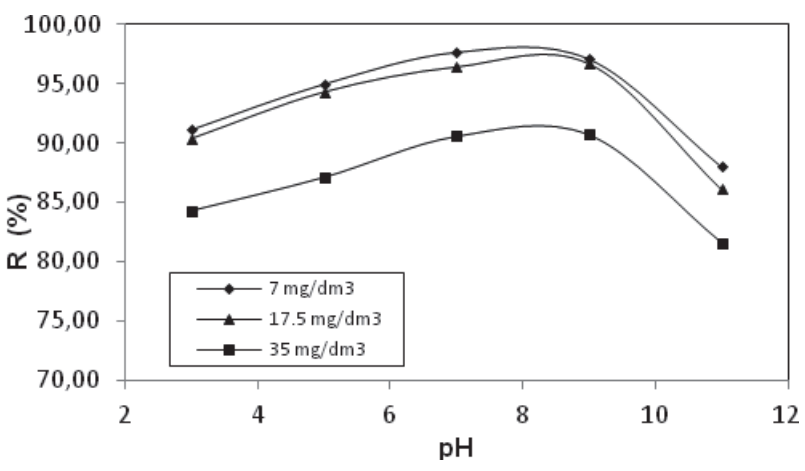

Fig. 2. The effect of $\mathrm{pH}$ on removal of $\mathrm{Pb}$ (II) on wheat bran, conditions: adsorbent dose $0.25 \mathrm{~g} / 50 \mathrm{~cm}^{3}, 25^{\circ} \mathrm{C}$.

(about 3), as a result of strong acidic medium. This could be due to the excess hydrogen ions surrounding the binding sites making adsorption unfavorable. As the $\mathrm{pH}$ increased the overall surface on wheat bran became negative and adsorption increased. Therefore, the $\mathrm{Pb}$ (II) ions up to $\mathrm{pH} 8$ would be interact more strongly with negatively charged binding sites. At higher $\mathrm{pH}>9$ the adsorption is followed by precipitation, respectively cations react with hydroxide ions and precipitate as hydroxides.

\section{Adsorption Isotherms Study}

Equilibrium study that gives the capacity of the adsorbent and adsorbate are described by adsorption isotherms, which represents the ratio between the quantity adsorbed and that remained in solution at equilibrium at constant temperature.

Several methods are often employed to interpret the equilibrium data. In the present study, the Langmuir and Freundlich adsorption isotherm models were used to explain the experimental results. The Langmuir isotherm describes monolayer adsorption on the surface of an adsorbent with e finite number of identical adsorption sites and no interaction between sites. The model is expressed as follows:

$$
\frac{1}{q_{e}}=\frac{1}{q_{\max }}+\frac{1}{K_{L} q_{\max }} \frac{1}{C_{e}}
$$

Linear form of the Equation 3 after rearrangement is given by:

$$
\frac{C_{e}}{q_{e}}=\frac{1}{K_{\mathrm{L}} q_{\max }}+\frac{1}{q_{\max }} C_{e}
$$

...where, $q_{\max }$ is the monolayer adsorption capacity (the maximum amount adsorbed) of the adsorbent $(\mathrm{mg} / \mathrm{g})$. The Langmuir adsorption constant $K_{L}\left(\mathrm{dm}^{3} / \mathrm{mg}\right)$ is an affinity parameter related to the energy of biosorption, $C_{e}$ is the equilibrium metal ion concentration in the solution $\left(\mathrm{mg} / \mathrm{dm}^{3}\right)$ and $q_{e}$, is the equilibrium metal ion concentration on the adsorbent $(\mathrm{mg} / \mathrm{g})$. When

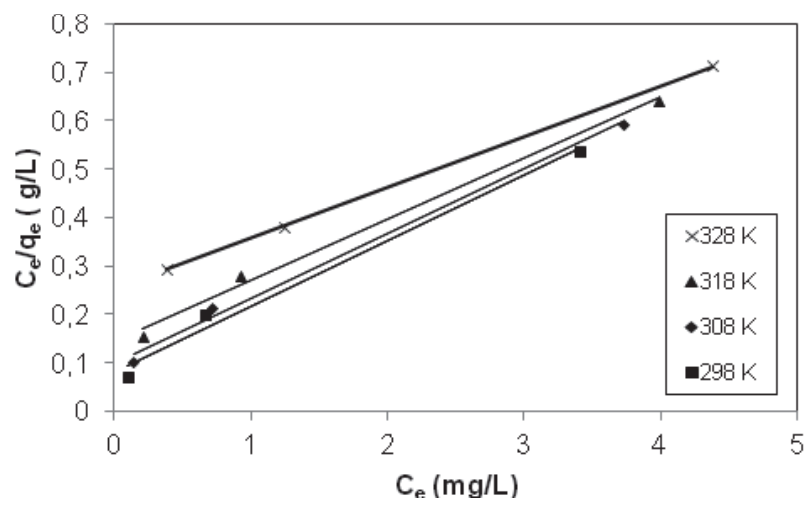

Fig. 3. Langmuir isotherm for $\mathrm{Pb}(\mathrm{II})$ ion adsorption at different temperatures, dose of adsorbent $0.25 \mathrm{~g} / 50 \mathrm{~cm}^{3}$.

$C_{e} / q_{e}$ is plotted against $C_{e}$, the values of $q_{\max }$ and $\mathrm{K}_{\mathrm{L}}$ were obtained from the slope and the intercept, which shows that adsorption of $\mathrm{Pb}$ (II) followed Langmuir isotherm model (Fig. 3).

The essential characteristics of a Langmuir isotherm can be described by a dimensionless constant separation factor or equilibrium parameter, $R_{L}$ which is defined by Equation 5:

$$
\mathrm{R}_{\mathrm{L}}=\frac{1}{\left(1+\mathrm{K}_{\mathrm{L}} \mathrm{C}_{\mathrm{o}}\right)}
$$

...where $C_{o}$, is initial metal concentration $\left(\mathrm{mg} / \mathrm{dm}^{3}\right)$ and $K_{L}$ is Langmuir constant. The separation factor $R_{L}$ indicates the isotherm shape as: $\mathrm{R}_{\mathrm{L}}<1$ favorable, $\mathrm{R}_{\mathrm{L}}>1$ unfavorable, $\mathrm{R}_{\mathrm{L}}=$ linear, $\mathrm{R}_{\mathrm{L}}=0$ irreversible. The data of equilibrium parameter $R_{L}$ are given in Table 2 .

The $\mathrm{R}_{\mathrm{L}}$ at different concentrations and temperatures (Table 2) are between 0 and 1, indicating a highly favorable adsorption of $\mathrm{Pb}(\mathrm{II})$ ion onto wheat bran.

The Freundlich model isotherm proposes heterogeneous energetic distribution of active sites. The Freundlich isotherm describes reversible adsorption and is not restricted to the formation of a monolayer. The Freundlich, model isotherm accompanied by interaction between adsorbed molecules. The Freundlich is an empirical equation (used to estimate the adsorption intensity of the sorbent toward the adsorbate) which is given by:

$\mathrm{q}_{\mathrm{e}}=\mathrm{K}_{\mathrm{F}} \mathrm{C}_{\mathrm{e}}^{1 / \mathrm{n}} \quad \log \mathrm{q}_{\mathrm{e}}=\log \mathrm{K}_{\mathrm{F}}+1 / \mathrm{n} \log \mathrm{C}_{\mathrm{e}}$

Table 2. Equilibrium parameters $\left(\mathrm{R}_{\mathrm{L}}\right)$.

\begin{tabular}{|c|c|c|c|c|}
\hline $\mathrm{C}_{\mathrm{o}}\left(\mathrm{mgL}^{-1}\right)$ & $298 \mathrm{~K}$ & $308 \mathrm{~K}$ & $318 \mathrm{~K}$ & $328 \mathrm{~K}$ \\
\hline 7 & 0.192 & 0.162 & 0.112 & 0.056 \\
\hline 17.5 & 0.087 & 0.071 & 0.048 & 0.023 \\
\hline 35 & 0.043 & 0.037 & 0.024 & 0.012 \\
\hline
\end{tabular}




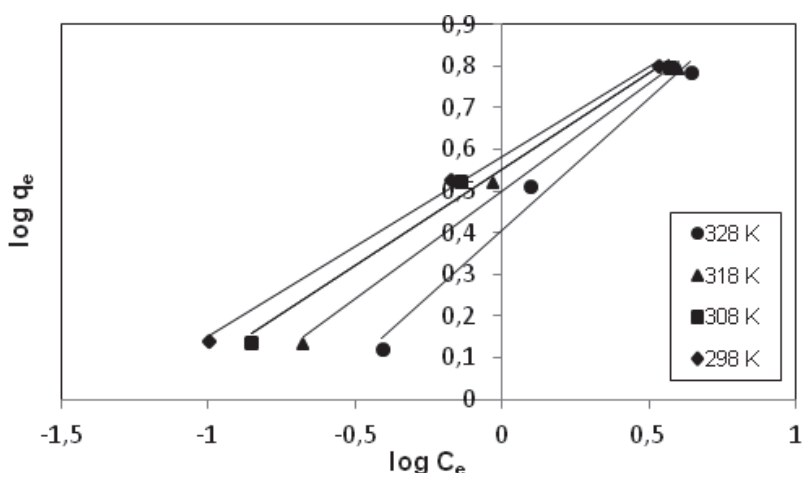

Fig. 4. Fruendlich isotherm for adsorption of $\mathrm{Pb}(\mathrm{II})$ ion, at different temperatures and adsorption dose $0.25 \mathrm{~g} / 50 \mathrm{~cm}^{3}$.

...where $K_{F}$ and $n$ are Freundlich constants, $K_{F}\left(\mathrm{mgg}^{-1}\right)$ $\left(\mathrm{Lmg}^{-1}\right)$ is related to uptake (adsorption) capacity and $1 / n$ is an empirical parameter related to the adsorption intensity, which varies with the heterogeneity of the material.

The constants $K_{F}$ and $1 / n$ were calculated from the slope and intercept Fig. 4.

Langmuir and Freundlich isotherm data are presented in Table 3.

The data in Table 3, show that the adsorption of $\mathrm{Pb}$ (II) ion on what bran fits well with the Langmuir and Freundlich isotherms. The correlation coefficient values (Table 3) approaching to one clearly suggests that Langmuir and Freundlich isotherms holds good to explain adsorption of $\mathrm{Pb}$ (II) ions on wheat bran. The $R^{2}$ of Langmuir model is slightly higher than Freundlich isotherm.

Confirming that, $\mathrm{Pb}(\mathrm{II})$ adsorption occurs on a homogeneous adsorbent surface. Forming a monolayer in which each adsorption site can take a single molecule of adsorbate with the same adsorption energy [26]. Table 3 shows the values of $q_{\max }$ decreased as the solution's temperature increased. The decreasing values of $q_{\max }$ with increasing temperature indicate that the $\mathrm{Pb}$ (II) ions are favorably adsorbed by wheat bran at low temperature, which shows that the adsorption process is exothermic. According to the results the Freundlich model was found to describe also adsorption successfully. The values of $K_{F}$, was decreased with increase the temperature of solution and $1 / n$ increase with increase of temperature. In addition, $1 / n$ was between 0 and 1 indicating that the sorption of $\mathrm{Pb}(\mathrm{II})$ ions into wheat bran was favorable under mentioned conditions.

The effect of a change in temperature on the sorption system was studied to determine the thermodynamic parameters of the process.

The effect of temperature of $\mathrm{Pb}$ (II) ions was studied by varying the temperature in the range $298-328 \mathrm{~K}$. The value of Gibbs free energy $\Delta G^{o}$ can be calculated by using the following equation:

$$
\Delta \mathrm{G}^{\mathrm{o}}=-\mathrm{RT} \ln \mathrm{k}_{\mathrm{e}},
$$

$k_{e}$, equilibrium constant is given by following equation:

$$
\mathrm{k}_{\mathrm{e}}=\mathrm{q}_{\mathrm{e}} / \mathrm{C}_{\mathrm{e}}
$$

$k_{e}$ is calculated at different temperatures using equation 8.

The relationship between Gibbs free energy change, entropy change $\left(\Delta S^{\circ}\right)$ and enthalpy change $\left(\Delta H^{\circ}\right)$ can be expressed as:

$$
\Delta G^{\mathrm{o}}=\Delta H^{\mathrm{o}}-T \Delta S^{\mathrm{o}}
$$

From Eqs $(7,9)$ we obtained:

$$
\ln \mathrm{e}_{\mathrm{e}}=-\Delta \mathrm{H}^{\mathrm{o}} / \mathrm{RT}+\Delta \mathrm{S} \% \mathrm{R}
$$

...where $\Delta H^{o}, \Delta S^{o}$ are standard enthalpy and entropy change.

The values of $\Delta \mathrm{H}^{\circ}$ and $\Delta \mathrm{S}^{\circ}$ were calculated from the slope and the intercept of the linear plot of $\ln _{e}$ vs $1 / T$ Fig 5.

The thermodynamic parameters of $\mathrm{Pb}(\mathrm{II})$ ions adsorption on wheat bran are given in Table 4 .

The results (Table 4) show that as temperature of solution increased the equilibrium removal of metal ions was decreased suggesting that temperature has the negative effect on the adsorption of $\mathrm{Pb}$ (II) ions onto wheat bran.

The magnitude of $\Delta \mathrm{G}^{\mathrm{o}}$ decreased with decreased temperature indicating spontaneous nature of the adsorption with high preference of metal ion for

Table 3. Langmuir and Freundlich constants of adsorption system at different temperatures.

\begin{tabular}{|c|c|c|c|c|c|c|}
\hline \multicolumn{4}{|c|}{ Langmuir isotherm parameters } & \multicolumn{3}{c|}{ Freundlich isotherm parameters } \\
\hline $\mathrm{T}(\mathrm{K})$ & $\begin{array}{c}\mathrm{q}_{\max } \\
\left(\mathrm{mgg}^{-1}\right)\end{array}$ & $\begin{array}{c}\mathrm{K}_{\mathrm{L}} \\
\left(\mathrm{Lmg}^{-1}\right)\end{array}$ & $\mathrm{R}^{2}$ & $1 / \mathrm{n}$ & $\begin{array}{c}\mathrm{K}_{\mathrm{F}} \\
\left(\mathrm{mgg}^{-1}\right)\left(\mathrm{Lmg}^{-1}\right)\end{array}$ & $\mathrm{R}^{2}$ \\
\hline 298 & 12.345 & 0.600 & 0.989 & 0.432 & 3.810 & 0.997 \\
\hline 308 & 10.101 & 0.739 & 0.995 & 0.462 & 3.556 & 0.989 \\
\hline 318 & 6.993 & 1.135 & 0.995 & 0.517 & 3.162 & 0.991 \\
\hline 328 & 3.968 & 2.400 & 0.999 & 0.632 & 2.540 & 0.984 \\
\hline
\end{tabular}




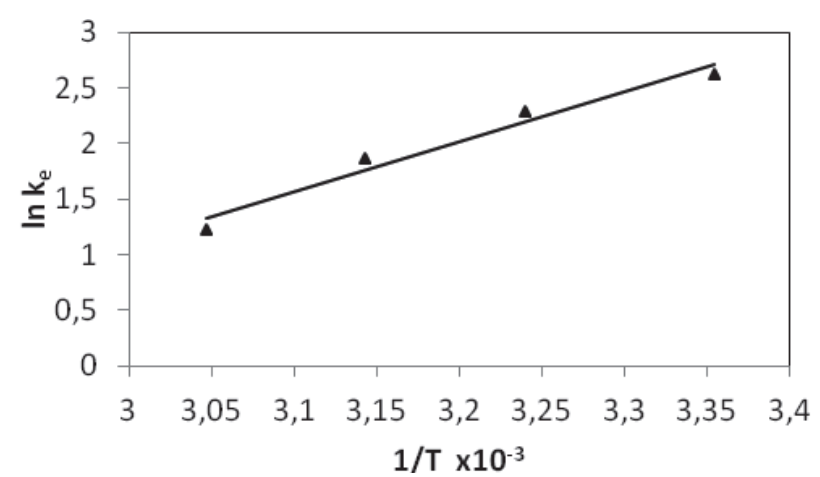

Fig. 5. Plot of $\ln k_{e}$ vs $1 / T$ for $\mathrm{Pb}$ (II) ions adsorption by wheat bran at different temperatures, initial conc. $7 \mathrm{mg} / \mathrm{dm}^{3}$ and adsorbent dose $0.25 \mathrm{~g} / 50 \mathrm{~cm}^{3}$.

Table 4. The thermodynamic parameters for adsorption of $\mathrm{Pb}$ (II) on wheat bran.

\begin{tabular}{|c|c|c|c|c|}
\hline $\mathrm{T}(\mathrm{K})$ & $\ln k_{e}$ & $\begin{array}{c}\Delta \mathrm{G}^{\circ} \\
(\mathrm{kJ} / \mathrm{mol})\end{array}$ & $\begin{array}{c}\Delta \mathrm{H}^{\circ} \\
(\mathrm{kJ} / \mathrm{mol})\end{array}$ & $\begin{array}{c}\Delta \mathrm{S}^{\circ} \\
(\mathrm{kJ} / \mathrm{Kmol})\end{array}$ \\
\hline 298 & 2.6246 & -6.50 & -37.52 & -0.104 \\
\hline 308 & 2.2824 & -5.844 & & \\
\hline 318 & 1.8666 & -4.935 & & \\
\hline 328 & 1.2207 & -3.328 & & \\
\hline
\end{tabular}

wheat bran, i. e. adsorption was more favorable at low temperature. It was found that $\mathrm{Pb}$ (II) adsorption on wheat bran has negative values of the enthalpy change $\Delta \mathrm{H}^{\circ}$ which means that adsorption is exothermic process. According to the absolute value of $37.52 \mathrm{~kJ} / \mathrm{mol}$ the $\mathrm{Pb}$ (II) adsorption on wheat bran could be physicalchemical process rather than pure physical or chemical respectively. Negative value of $\Delta \mathrm{S}^{\circ}$ suggests a decrease in randomness at the solid/solution interface during the adsorption process and reflects the affinity of the wheat bran for $\mathrm{Pb}(\mathrm{II})$ ions, while low value of $\Delta \mathrm{S}^{\circ}$ indicates that no remarkable change on entropy occurs.

Although most industrial effluents are composed of a multi-metal system, relatively fewer studies have been conducted on competitive coexisting removal of metal ions from multi-metal systems compared to singlemetal solution and also hybrid processes. In the present work the adsorption of $\mathrm{Pb}$ (II) ions was near the same in single compared to multi-metal ions in aqueous solution, $\mathrm{q}=5.46 \mathrm{mg} / \mathrm{g}$ or $91 \%$, and $\mathrm{q}=5.44 \mathrm{mg} / \mathrm{g}$ or $90.74 \%$ for the relatively near the same metal concentration.

It is evident that adsorption of $\mathrm{Pb}$ (II) ion was much higher of other metal ions i.e. wheat bran had strong affinity to $\mathrm{Pb}(\mathrm{II})$ ion from aqueous solution that other competitive ions. Therefore, $\mathrm{Pb}$ (II) ion is effectively removed from solution in presence of other metal ions. However, the removal of $\mathrm{Cd}(\mathrm{II})$ ions for example was lowered significantly $\mathrm{q}=4.24 \mathrm{mg} / \mathrm{g}$ or $67 \%$ in comparison with $\mathrm{q}=2.33 \mathrm{mg} / \mathrm{g}$ or $38.33 \%$ in presence of $\mathrm{Pb}(\mathrm{II})$ ions respectively. The other metal ions were also suppressed in presence of $\mathrm{Pb}(\mathrm{II})$ ion, the results consistent with those published in literature [18].

In the current study the experimental results of the uptake of thermal power plants wastewater system conducted under the same conditions as batch experiments at $\mathrm{pH} 8.35$ are given in Table 5 .

The order of metal ions uptake from used wastewater sample was as follows:

$$
\mathrm{Cr}^{3+} \geq \mathrm{Cd}^{2+}>\mathrm{Ni}^{2+}>\mathrm{Mn}^{2+}>\mathrm{Zn}^{2+}
$$

This uptake order is understandable due to preference of surface charged groups of wheat bran for specific ions, hydration energy of ions, ionic radius, electronegativity etc.

Although the removal efficiency of $\mathrm{Pb}(\mathrm{II})$ ions by wheat bran was lowered compared to single and multimetal synthetic system in aqueous solution (Table 5), its uptake is comparable with high removal efficiency adsorbents [13].

The data presented in Table 5 shows that removal of $\mathrm{Pb}$ (II) and most co-existing ions by wheat bran was very high in thermal power plants wastewater effluents. Thus wheat bran looks preferable biosorbent for waste water treatment containing metal ions of low concentration. It exhibits also significant potential for pre-treatment of such and similar wastewater prior reverse osmosis treatment.

Therefore, the retentate of power plants wastewater sample pretreated with wheat bran as biosorbent was used for reverse osmosis test (Table 5). These results confirm that removal of $\mathrm{Pb}(\mathrm{II})$ and coexisting metal ions of pretreated water (retentate) could attain 100\% by hybrid processes under experimental conditions used in this work. The resultant effluent seems promising for water re-use.

Table 5. The data of heavy metal content in wastewater effluents sample of thermal power plants (Kosova B), pretreated with wheat bran and treated by heterogeneous reverse osmosis membranes (batch 317) at pressure 1,76 MPa. Specific conductivity: $337 \mu \mathrm{S}$ at $25^{\circ} \mathrm{C}, \operatorname{COD} 13.8 \mathrm{mg} / \mathrm{dm}^{3}$.

\begin{tabular}{|c|c|c|c|}
\hline Elements & $\begin{array}{c}\text { Feed } \\
\left(\mathrm{mg} / \mathrm{dm}^{3}\right)\end{array}$ & $\begin{array}{c}\text { Pretreated with } \\
\text { wheat bran } \\
\left(\mathrm{mg} / \mathrm{dm}^{3}\right)\end{array}$ & $\begin{array}{c}\text { Treated with } \\
\text { RO } \\
\left(\mathrm{mg} / \mathrm{dm}^{3}\right)\end{array}$ \\
\hline $\mathrm{Pb}$ & 0.072 & 0.011 & $<1 \mathrm{ppb}$ \\
\hline $\mathrm{Cd}$ & 0.011 & $<1 \mathrm{ppb}$ & $<1 \mathrm{ppb}$ \\
\hline $\mathrm{Ni}$ & 0.007 & 0.001 & $<0.5 \mathrm{ppb}$ \\
\hline $\mathrm{Zn}$ & 0.091 & 0.038 & 0.003 \\
\hline $\mathrm{Mn}$ & 0.32 & 0.071 & 0.004 \\
\hline $\mathrm{Cr}$ & 0.005 & $<1 \mathrm{ppb}$ & $<1 \mathrm{ppb}$ \\
\hline $\mathrm{pH}$ & 8.35 & 7.55 & 7.70 \\
\hline
\end{tabular}




\section{Conclusions}

The rapid uptake and high removal efficiency of $\mathrm{Pb}$ (II) ions with wheat bran express favorable adsorption of $\mathrm{Pb}$ (II) ions from aqueous solutions. The adsorption process was dependent upon the $\mathrm{pH}$ of medium, contact time, ion concentration and adsorbent dose. The adsorption equilibrium data fit well both Langmuir and Freundlich adsorption isotherms. The thermodynamic parameters showed the spontaneous and the exothermic nature of the adsorption process. The results of $\mathrm{Pb}(\mathrm{II})$ and other coexisting ions removal from wastewater effluents of power plants pre-treated by wheat bran showed good performance for use prior reverse osmosis treatment. Hybrid processes seem to be effective for successful rejection $\mathrm{Pb}$ (II) and other metal ions from wastewater justifying their application for water re-use.

\section{Conflict of Interest}

The authors declare no conflict of interest.

\section{References}

1. WANG J., CHEN C. Biosorbents for heavy metals removal and their future. Biotechn. Adva. 27 (2), 195, 2009.

2. MATHEW B.B., JAISHANKAR M., BIJU V.G., BEEREGOWDA K.N. Role of Biosorbents in Reducing Toxic Metals. J. of Toxicol. 13 (10), 1, 2016.

3. PARK D., YUN J. S. The past, present, and future trends of biosorption. Biotech. and Biopro. Engin. 15 (1), 86, 2010.

4. QAISER S., SALEEMI A. R., UMAR M. Biosorption of lead(II) and $\mathrm{Cr}(\mathrm{VI})$ on ground nut hull: Equilibrium, kinetics and thermodynamics study. Elect. J. of Biotech.12 (4), 1, 2009.

5. REDDY D.H.K., HARINARTH Y., SESHAIAH K., REDDY A.V.R. Biosorption of $\mathrm{Pb}(\mathrm{II})$ from aqueous solutions using chemically modified Moringa oleifera tree leaves. Chem. Engin. J. 162 (2), 626, 2010.

6. KAFIA M., SURCHI SH. Agricultural Wastes as Low Cost Adsorbents for $\mathrm{Pb}$ Removal: Kinetics, Equilibrium and Thermodynamics, Intern. J. of Chem. 3 (3), 103, 2011.

7. ANWAR J., SHAFIQUE U., ZAMAN W., SALAM M., DAR A., ANWAR Sh. Removal of Pb (II) and Cd (II) from water by adsorption on peels of banana. Biosur. Technol. 101 (6), 1752, 2010.

8. ATA S., DIN M.I., RASOL A., QASIM I., MOHSIN I. U., Equilibrium, Thermodynamics and Kinetic Sorption Studies for the Removal of Coomaassie Brilliant Blue on Wheat Bran as a low-Cost Adsorbent. J. of Anal. Meth. Chem. 20 (3), 8, 2012.

9. WARREN R-R., WALTER J.C-V., MARIA E.K-S., WALTER F.Z.A., RICARDO A.Y.P., Evaluation of $\mathrm{Pb}$ (II) Adsorption from Aqueous Solutions Using Brassica nigraas a Biosorbent. The Open Biotech. J. 13, (1), 77, 2019.

10. XIOA-KUN Y.O., LE-PING Y., ZHENG-SHUM W. Adsorption of $\mathrm{Pb}^{2+}$ from solution using Peanut Shell as
Biosorbent in the Presence of Amino Acid and Sodium Chloride, BioResources. 9 (2), $2446,2014$.

11. FRANCISCA J A., LORENA A., IRENE G-D., FELIX A L, Removal of $\mathrm{Pb}^{2+}$ in Wastewater via Adsorption onto an Activated Carbon Produced from Winemaking Waste. Metals. 697 (8), 1, 2018

12. MUHAMMAD N.Z., MUYNA S., RAZIYA N., SAJJAD H.S., SYED S.SH., MUHAMMAD AQ. Chemical pretreatments of Trapabispinosa's peel (TBP) biosorbent to enhance adsorption capacity for $\mathrm{Pb}(\mathrm{II})$. Open Chem. 17 (1), 325, 2019.

13. NISHA G., AAYUSH K., MAHAVIR Y., ARCHANA T., Adsorptive removal of lead and arsenic from aqueous solution using soya bean as a novel biosorbent: equilibrium isotherm and thermal stability studies, Appl. Water Scien. 8 (4), 98, 2018.

14. YAYUAN H., PIAN W., WEN X., GUIYIN L., JIECAN Y., YAFEI H., CUIMEI CH., PING D., YANYING D., Efficient removal of $\mathrm{Pb}$ (II) from aqueous solution by a novel ion imprinted magnetic biosorbent: Adsorption kinetics and mechanisms. PLoS ONE. 14 (3), 1, 2019.

15. XIN H., JIACHANG C., HANYU Y., DAHUI L., YUE Q., JIALIN Z.H., ZHIXIA Z.H., LEI H. $\mathrm{Pb}^{2+}$ biosorption from aqueous solutions by live and dead biosorbents of the hydrocarbon-degrading strain Rhodococcus sp. HX-2. PLoS ONE. 15 (1), 24, 2020.

16. CIMA-MUKUL C.A., YOUNESS A., MOHAMED A., JOEL V., ARLETTE A.S., JESUS A.B.Z. Eco-Efficient Biosorbent Based on Leucaena leucocephala Residues for the Simultaneous Removal of $\mathrm{Pb}$ (II) and $\mathrm{Cd}(\mathrm{II})$ Ions from Water System: Sorption and Mechanism. Bioinorg. Chem. and Applic. 13 (1) 1, 2019.

17. FEYZA E., ŞERIF T., VEDIA N.T. Removal of lead from aqueous solutions by low cost and waste biosorbents (lemon, bean and artichoke shells). Water Sci. and Tech. 81 (1), 159, 2020.

18. COURTIE $\mathrm{M}$. On the dominance of $\mathrm{Pb}$ during competitive biosorption from multi-metal systems: A review. Cogent Environ. Scie. 5 (1), 1, 2019.

19. EZUGBE E.O., RATHILAL S. Membrane Technologies in Wastewater Treatment: A Review. Membrane. 10 (5), 89, 2020.

20. SINGH R., HANKINS N., Emerging Membrane technology for Sustainable water treatment, Elsevier, Amsterdam, The Netherlands 2016.

21. PETRINIC I., KORENAK J., POVODNIK D., HELIXNIELSEN C. A feasibility study of ultrafiltration/reverse osmosis (UF/RO) - based wastewater treatment and reuse in metal finishing industry. J. Clean. Prod. 101, 292, 2015.

22. STEPHANIE M. R., OLIVEIRA J. M. S., REGNERY J., CATH T.Y. Hybrid membrane bio-systems for sustainable treatment of oil and gas produced water and fracturing flow back water. Sep. Purif. Techn. 171 (38), 297, 2016.

23. THAÇI S.B., GASHI T.S., Reverse Osmosis Removal of Heavy Metals from Wastewater Effluents Using Biowaste Materials Pretreatment. Pol. J. Environ. Stud. 28 (1), 337, 2019.

24. GASHI T. S., DACI N. M., PODVORICA F., SELIMI T., THAÇI S. B. Effect of modification time of coal with aryldiazonium salts on the performance of cellulose acetate-coal heterogeneous reverse osmosis membranes. Desalination. 240 (1) 1, 2009.

25. THAÇI S.B., GASHI T.S., PODVORICA F. Preparation of heterogeneous reverse osmosis membranes undergoing modification process. Des. Water Treat. 118 (2) 96, 2018.

26. BASU M., GUHA A. K., RAY L. Adsorption of Lead on Cucumber Peel. J. Clean Prod. 151 (1), 603, 2017. 